\title{
Performance Analysis of Electronic Single-phase Watt-hour Meter
}

\author{
Huang Xuemei
}

Power Metering Center, Hainan Power Grid Co., Ltd., Haikou, Hainan 570100

\begin{abstract}
The meter has a very close relationship between the measurement performance and the measurement chip. However, there is a certain defect in the operation of this type of energy meter. Once the measurement chip is unreasonable, there is a certain degree of waste of electricity. In this paper, several kinds of electronic single-phase energy meter to simulate the practical application of the special test, and the performance of these metering chip were analyzed and studied.
\end{abstract}

Key words: electronic single-phase energy meter; metering chip; performance analysis

\section{Introduction}

With the continuous development of China's manufacturing process, making the electronic single-phase energy meter has also been a certain degree of development. Compared with the traditional induction energy meter, electronic energy meter with high measurement accuracy and high dose rate and many other advantages, its manufacturing and other industries for the development of China also has a very important significance ${ }^{1}$. This also requires the electronic single-phase energy meter to measure the performance of the chip to continue to improve and optimize, and make its measurement performance can be closer to the development.

First, the way energy meter metering quality

As the heart of the electronic energy meter, in the process of measuring the design of the chip also requires its meter to meet the corresponding standards and procedures of technical requirements, but in the design of the meter used in the process, also need to measure the energy meter as well as the quality of the reasonable evaluation and assessment, which for the electronic single-phase energy meter optimization and improvement also has a very important significance ${ }^{2}$. At this stage in the electronic single-phase energy meter metering performance testing process, there are two main measurement methods.

\section{(A) Laboratory tests}

The test method needs to be tested under laboratory conditions according to the relevant technical standards or regulations. The test method needs to be carried out under normative experimental conditions and has a relatively high test technical requirement. Although the high efficiency of such tests, the content is more comprehensive, but the pilot project has a certain representation, it cannot be applied in some special occasions. For example, although some of the test methods of the wiring method can be in the laboratory test process to obtain a good test results, but its practical application with the situation there is still some differences, and lead to qualified meter and the actual conditions exist abnormal performance.

(B) Analysis of long-term operational data

The method is mainly in the long-term operation of the meter or the use of the process of exposure to the problem of analysis, and the performance of the meter to a reasonable evaluation. Because the results of the actual operation on the basis of the performance of the meter analysis, so the test results have a very strong objectivity, and can be used as a laboratory test work to continue and supplement. Through this type of test method, which can further enhance the performance of new energy meter and quality analysis results.

At present, the electronic single-phase energy meter has a good use of performance, but at this stage of the power sector and the energy meter production plant in 
the relevant information that electronic single-phase energy meter in the measurement process of some of the performance still exists with a certain problem.

Second, the electronic single-phase energy meter measurement chip performance analysis

In order to verify these cases, it is necessary in the laboratory case to several common energy meter to use the design study, and the need for different chip-like test work. The sample chips taken in this study are AD7755, ADE7755, BL0932B, SPM3D-20 and TKMC33035, and these three types of chips were tested for start-up power, cyclic loading and unloading test, power failure test and load change test. Four tests, the specific test results are shown below.

Compared with the traditional induction energy meter, electronic energy meter also has the advantage of high sensitivity. The results of the related starting power test show that when the starting power of the meter is $0.2 \sim 0.5 \mathrm{~W}$, the sensitivity of the starting power is different ${ }^{3}$. Therefore, to ensure that the technical indicators of the meter fully meet the requirements of the national technical regulations under the premise of a good starting power sensitivity, so that not only can be fair measurement, but also to the distribution line management level to further improve the level to provide more technical support. In the process of adding an unloading test by cycle, it was also found that the various chips did not lose the check pulse under the actual operating conditions.

On the use of several metering chip power outage study found that no matter what kind of chip, in the specific operation of the process will be lost to a number of $\mathrm{CP}$ pulse, which is also composed of a principle defects of electronic single-phase meter metering chip. In addition cost of a single-phase energy meter is an important economic and technical indicators. China's current stage for the electronic single-phase meter development time is relatively short, and electrical production technology and the current level of electronic single-phase meter development level, in order to maintain these pulses also need to pay more expensive cost. And as a qualified design, if the power-on reset line has the correct and reliable logic, will not lose the pulse will not affect the electronic single-phase energy meter performance.
Table 1 analysis, found that the electricity sector and the relevant energy meter production plant to reflect the situation consistent, the load change test results also show that, AD7755 chip in the load changes in the upper limit of $3.3 \mathrm{~W}$, the school test pulse and stepper motor drive pulse display there is a certain degree of difference, which is likely to lead to the loss of electricity this situation occurred. Every $20 \mathrm{~min}$ refrigerator start and stop once, a month of the refrigerator will start 2160 times, in which case the probability of pulse loss will reach $87.5 \%{ }^{4}$. When a family in the use of refrigerators in the process, its monthly electricity consumption will even reach $1.5 \mathrm{kWh}^{5}$. In order to effectively solve this problem, it is necessary to reproduce the chip design, and its external circuit design to improve and optimize.

\begin{tabular}{|c|c|c|c|c|c|c|c|c|c|c|c|}
\hline \multirow[t]{2}{*}{ Line name } & \multirow[t]{2}{*}{ Type } & \multicolumn{2}{|c|}{ Specified voltage } & \multicolumn{2}{|c|}{ Actual voltage range } & \multirow{2}{*}{$\begin{array}{l}\text { General } \\
\text { examinati } \\
\text { on time } \\
\text { (h) }\end{array}$} & \multirow{2}{*}{$\begin{array}{l}\text { Upper } \\
\text { limit of } \\
\text { time (h) }\end{array}$} & \multirow{2}{*}{$\begin{array}{l}\frac{\text { Lower }}{} \\
\text { limit of } \\
\text { Time (h) }\end{array}$} & \multirow{2}{*}{$\begin{array}{c}\text { Passing } \\
(\%)\end{array}$} & \multicolumn{2}{|c|}{ Accumulated time } \\
\hline & & $\begin{array}{l}\text { Upper } \\
\operatorname{limit}(\mathrm{kV})\end{array}$ & $\begin{array}{l}\text { Lower } \\
\text { limit }(k \mathrm{~V})\end{array}$ & $\begin{array}{l}\text { Highest } \\
\text { voltage } \\
\text { (kV) }\end{array}$ & $\begin{array}{l}\text { Lowest } \\
\text { voltage } \\
(\mathrm{kV})\end{array}$ & & & & & $\begin{array}{l}\text { Upper } \\
\text { limit of } \\
\text { time (h) }\end{array}$ & $\begin{array}{l}\text { Lower } \\
\text { limit of } \\
\text { time (b) }\end{array}$ \\
\hline $220 \mathrm{kV}$ I line & voltage A & 232.00 & 222.00 & 230.77 & 222.44 & 514.68 & 0.00 & 0.00 & 100.00 & 0.00 & 0.00 \\
\hline 220kV IIline & roltage A & 232.00 & 222.00 & 232.61 & 226.23 & 514.68 & 1.78 & 0.00 & 99.65 & 1.78 & 0.00 \\
\hline 110kV Iline & roltage A & 118.00 & 108.00 & 121.94 & 116.67 & 514.68 & 506.60 & 0.00 & 1.57 & 506.60 & 0.00 \\
\hline 110kV IIline & roltage A & 118.00 & 108.00 & 121.80 & 116.55 & 514.68 & 503.85 & 0.00 & 2.10 & 503.85 & 0.02 \\
\hline 10kV I line PT & voltage A & 10.70 & 10.00 & 10.49 & 10.13 & 514.68 & 0.00 & 0.00 & 100.00 & 0.00 & 0.00 \\
\hline 10kV II line PT & voltage $B$ & 10.70 & 10.00 & 10.57 & 10.20 & 514.68 & 0.00 & 0.00 & 100.00 & 0.00 & 0.00 \\
\hline
\end{tabular}

Table 1: Monthly voltage statistics

\section{Conclusion}

In recent years, China's electronic single-phase energy meter has been a certain degree of development, and single-phase meter in the electricity meter market share has also been a greater degree of improvement. However, in the daily work of electronic single-phase energy meter, its work results and measurement accuracy and measurement chip design there is a close relationship. In this paper, the performance of the electronic single-phase energy meter metering chip is analyzed and studied, and the working performance of the metering chip is expounded, hoping to provide enough theoretical support for the continuous optimization and improvement of our single-phase watt-hour meter.

\section{References}

[1] Zhou Zhahua. Electronic Single-Phase Energy Meter Anti-Tampering Principle and Miswiring Analysis [J]. Enterprise technology development (the second half), 2016, 35 (21): 47-48.

[2]Chen, S. and Yang, Z., 2012, April. A low cost single phase PLC watt-hour meter based on SoC. In Consumer Electronics, Communications and 
Networks (CECNet), 2012 2nd International Conference on (pp. 1523-1526). IEEE.

[3] Basile, B., Schauer, S. and Venkat, K., 2012. Implementation of a Single-Phase Electronic Watt-Hour Meter Using the MSP430F6736.

[4] Huang, J.Y., Li, S.Y., Guo, M.F., Yang, G.J. and Gao, W., 2010. Design of short-distance wireless communication interface for single-phase electronic watt-hour meter. Power System Protection and Control, 38(24), pp.172-177.

[5] Nayak, P., 2013. Implementation of single phase watt hour meter using LPC2148 (Doctoral dissertation).

[6] Kling A. Andrew, (2010). Cell Phones. 27500 Drake Road,

Far. Hills MI 48331: Lucent Books

[7] Magnay Jacquelin, (2014). Ticket swindle leaves trail of losers, Sidney Morning Herald, August 4, 2014

[8 McFedries Paul, (2004). Word spy: the word spy: the word lover's guide to modern culture,
New York, Broadway Books

[9] Neufeld Evan, (2007). Common Short Codes:

Cracking The Mobile Marketing Code,

Seattle, M:Metrics

[10] Reid H. Robert (1997). Architects of the Web: 1,000 Days that Built the Future of Business,New York, John Wiley \& Sons, 1997

[11] Summers J. Bruce, (2012). Payment Systems: Design, Governance and Oversight, Central Banking Publications Ltd, London, 2012.

[12] Trattner Cristoph \& Kappe Frank, (2013). Social Stream Marketing on Facebook: A case Stady, International Journal of Social and Humanistic Computing - IJSHC 2 1/2, 2013.

[13] Ward Susan, (2014). Online Marketing, http://sbinfocanada.about.com/od/marketing/g/onlinem arketing.htm

[14] Woolsey Ben and Emily Starbuck Gerson,(2016). The history of credit cards, http://www.creditcards.com/credit-card-news/cr edit-cards-history-1264.php 